九州大学学術情報リポジトリ

Kyushu University Institutional Repository

Field Studies on Wild Bee Fauna and Pollination Biology for Combating Desertification and Planting Campaigns in Asian Air Areas: A Report for the Year 2000 to 2004

Tadauchi, 0samu

https://doi.org/10.5109/2698

出版情報 : ESAKIA. 45，pp.1-8，2005-03-31. Entomological Laboratory，Faculty of Agriculture， Kyushu University

バージョン :

権利関係 : 
ESAKIA, (45): 1-8. March 31, 2005

\title{
Field Studies on Wild Bee Fauna and Pollination Biology for Combating Desertification and Planting Campaigns in Asiam Arid Areas: A Report for the Year 2000 to 2004 $4^{1,2}$
}

\author{
Osamu TADAUCHI \\ Entomological Laboratory, Faculty of Agriculture, Kyushu University, \\ Fukuoka, 812-8581 Japan
}

\begin{abstract}
Desertification has rapidly progressed in arid areas of Asia. Various practices aimed at combating desertification have been implemented in many countries. Although planting campaigns have been tried and continue to be used, basic information on wild bees which pollinate plants in desert and semi-desert areas is insufficient. Wild bees are very important insects for the pollination of semi-desert plants. We conducted five surveys in Kazakhstan, Kyrgyzstan and northwestern China from 2000 to 2004 . We collected about 30,000 bee specimens and studied the taxonomy and biogeography of these wild bees. We found some useful pollinating wild bee species and studied the nesting biology of these bees in the field.
\end{abstract}

Key words: Wild bee fauna, pollination biology, combat desertification, planting campaign, Kazakhstan, Kyrgyzstan, northwestern China.

\section{Introduction}

Desertification has rapidly progressed in arid areas of Asia. It is a land degradation problem of major importance in arid regions. Deterioration in soil and plant cover has adversely affected nearly 50 percent of the land areas as a result of the human mismanagement of cultivated and range lands. Overgrazing and woodcutting are responsible for most of the desertification of rangelands, cultivation practices inducing accelerated water and wind erosion are mostly responsible in the rain-fed croplands, and improper water management leading

1) Contribution from the Entomological Laboratory, Faculty of Agriculture, Kyushu University, Fukuoka (Ser. 6, No. 7).

2) This work was supported by a Grant-in-Aid for Scientific Research (B) (2) from the Japan Society for the Promotion of Science (No. 14405025) (Head investigator: O. Tadauchi). 
to salinization is the cause of the deterioration of irrigated lands (Dregne, 1986). Various practices aimed at halting desertification have been employed in many countries of Asia, such as the planting of trees on bare mountains in China by the Japanese citizens group Green Earth Network in cooperation with the Chinese Communist Party's local youth committee since 1992 (ECES, 2004). Although planting campaigns have been tried and continue to be used, basic information on wild bees which pollinate plants in desert and semi-desert areas is insufficient. Wild bees are very important insects for the pollination of plants in arid areas. We therefore conducted surveys to accumulate basic information on wild bees to assist planting campaigns in Central Asia and northwestern China from 2000 to 2004 under the project titled "Field Studies of Wild Bee Fauna and Pollination Biology for Combating Desertification and Planting Campaign in Asian Arid Areas". The aims of the project are as follows: 1) To search and discover useful pollinating insects in semi-desert areas, 2) To collect wild bees in semidesert areas and to conduct taxonomic and biogeographical studies, and 3) To study pollinating and nesting behaviors of the useful bees.

\section{Fielld surveys and members}

We conducted five field surveys in the present project in Kazakhstan, Kyrgyzstan and northwestern China (Xinjiang Uygur Autonomous Region) from 2000 to 2004, including a preparatory survey in 2000. The areas surveyed are shown in Fig. 1 (China) and Fig. 2. (Kazakhstan and Kyrgyzstan). Details and members participating in the field surveys are as follows:

1. 2000. Preparatory survey May 23 to 31

Survey areas: Kazakhstan (Almaty and suburbs) - Kyrgyzstan (Bishkek, Ysykata) Kazakhstan (Almaty and suburbs).

Investigators: Osamu Tadauchi (Kyushu University), Shuichi Ikudome (Kagoshima Women's Junior College), Dawut Ahmatjan (Kyushu University).

2. 2002. August 19 to September 13 (Figs. 2)

Survey areas: Aug. 22-28, China (Xinjiang Uygur Autonomous Region: UrumuqiTurpan-Kuitun-Yining-Sayram Lake-Kuitun-Jeminay-Altai-Urumuqi); Aug. 31 to September 8, Kazakhstan (Almaty-Big Almaty Lake-Kurday-Taraz-Jabagly-Akusu Valley-Almaty).

Investigators:

Japan: Osamu Tadauchi (Kyushu University), Shuichi Ikudome (Kagoshima Women's Junior College), Ryoichi Miyanaga (Shimane University), Dawut Ahmatjan (Kyushu University), Ryuki Murao (Kyushu University).

China: Wang DengYuan (Xinjiang Agricultural University, Urumuqi), Niu ZeQing (Zoological Insitute, Chinese Academy of Sciences, Beijing). 


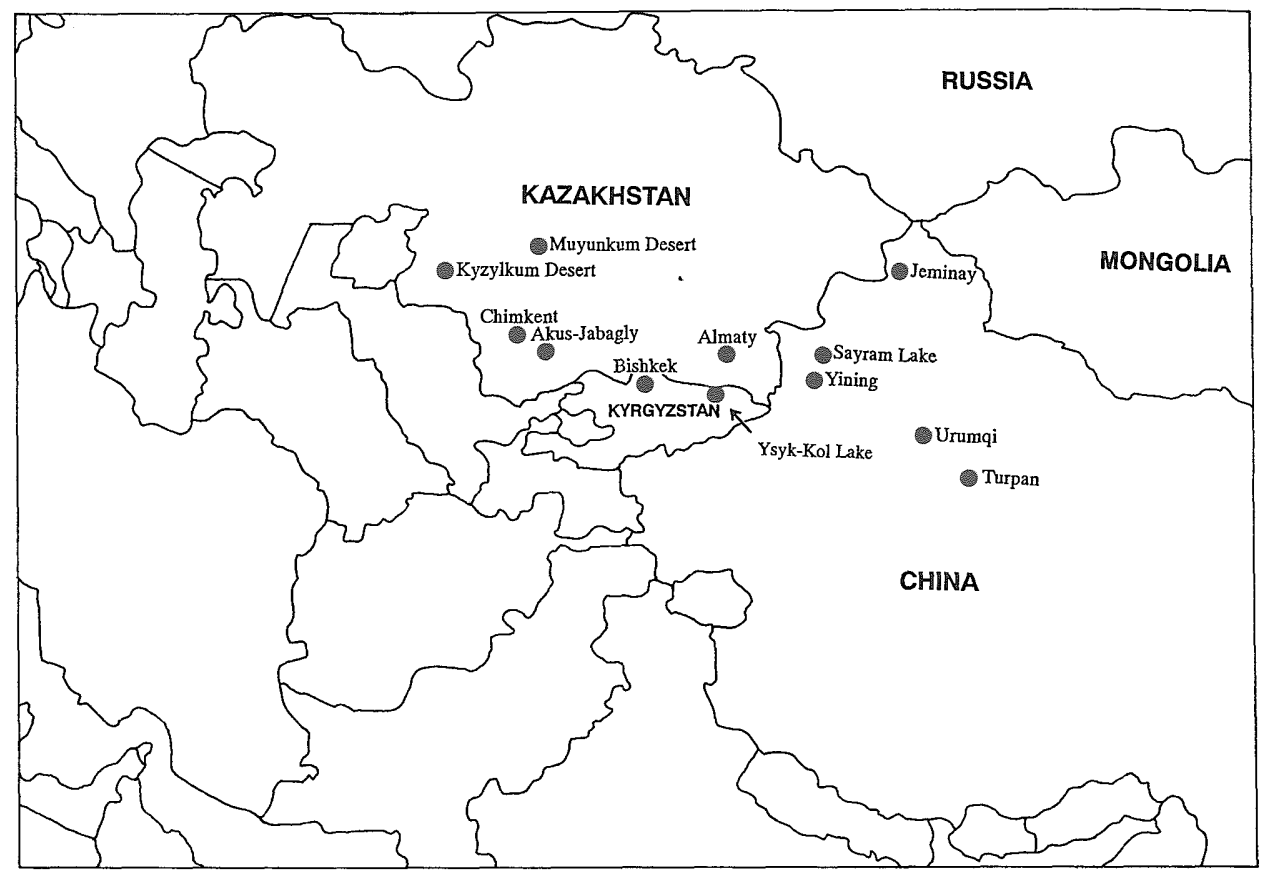

Fig. 1. Map of field survey areas in Kazakhstan, Kyrgyzstan and Xinjiang Uygur Autonomous Region, China.

Kazakhstan: Vitaly Kastcheev (Zoological Institute, Kazakhstan Academy of Sciences, Almaty), Roman Jaschenko (Zoological Institute, Kazakhstan Academy of Sciences, Almaty).

3. 2003. May 23 to June 20 (Figs. 3-5)

Survey area: Kazakhstan (Almaty-Jabagly-Chimkent-Otrar-Kentau-Mts. KaratauJanatas-Jarekbas-Akbastau-Jabagly-Akus Valley-Almaty-Big Almaty Lake).

Investigators:

Japan: Osamu Tadauchi (Kyushu University), Ryoichi Miyanaga (Shimane University), Satoshi Kamitani (Kyushu University), Katsushi Mitai (Kyushu University).

Kazakhstan: Vitaly Kastcheev (Zoological Institute, Kazakhstan Academy of Sciences, Almaty), Roman Jaschenko (Zoological Institute, Kazakhstan Academy of Sciences, Almaty).

4. 2003. August 19 to 30

Survey area: Kyrgyzstan (Bishkek-Ala Archa-Ysyk Ata-Bishkek-YsykKol LakeKarakol-Bishkek).

Investigators: Osamu Tadauchi (Kyushu University), Junichi Yukawa (Kyushu University), Ryoichi Miyanaga (Shimane University), Daisuke Yamaguchi (Kyushu 
University), Tomoko Ganaha (Kyushu University).

5. 2004. April 26 to May 24 (Figs. 6-9)

Survey area: Kazakhstan (Almaty-Kordai-Jabagly-Chimkent-Chordara-Lake Charbarinskoe-

Kyzylkum Desert-Syrdarya River-Mts. Karatau-Jabagly-Taras-Karatau-Janatas-

Muyunkum Desert-Kumozek-Moyenkum-Chu-Cordai-Almaty-Kapchagay-Ili riversideAlmaty-Medeu).

Investigators:

Japan: Osamu Tadauchi (Kyushu University), Ryoichi Miyanaga (Shimane University), Ryuki Murao (Kyushu University).

Kazakhstan: Roman Jaschenko (Zoological Institute, Kazakhstan Academy of Sciences, Almaty).

\section{Summary of results}

\section{Survey of wild bee fauna}

We collected about 30,000 wild bee specimens in Kazakhstan, Kyrgyzstan and the Xinjiang Uygur Autonomous Region of China. It is thought that bees show more diversity in arid areas of the temperate zones rather than the tropical zones (Michener, 1979, 2000). Among the arid temperate zones in the world, Central Asia has the least information on bees because of the fewer number of expeditions conducted in this region. The Zoological Institute of the Kazakhstan Academy of Sciences (Almaty), and the Zoological Institute of the Chinese Academy of Sciences granted permission for all specimens collected in this survey to be brought back to Japan for the purpose of studying the taxonomy and biogeography of these wild bees. Half of the identified specimens will be returned to the aforementioned institutes at some time in the future. The remaining specimens will be kept in the collection of the Entomological Laboratory, Faculty of Agriculture, Kyushu University. All specimens collected in the project have been pinned and labeled. We have studied some of the groups of bees collected, such as Andrena belonging to the family Andrenidae and Halictus (Seladonia) belonging to Halictidae and have published taxonomic revisions which include many new species (Dawut \& Tadauchi, 2001, 2002a, 2002b, 2003; Xu \& Tadauchi, 2001, 2002; Tadauchi \& Xu, 2002, 2003, 2004; Xu, Tadauchi \& Wu, 2002). We also borrowed undetermined specimens collected in Central Asia from the American Museum of Natural History, New York, and have added this borrowed collection to our taxonomic studies.

\section{Search for useful bees and field studies of the nesting structure of wild bees}

We searched for useful bees which pollinate semi-desert plants. We found some useful and dominant species in the semi-desert areas and have studied nesting structures. We will publish the results separately. 


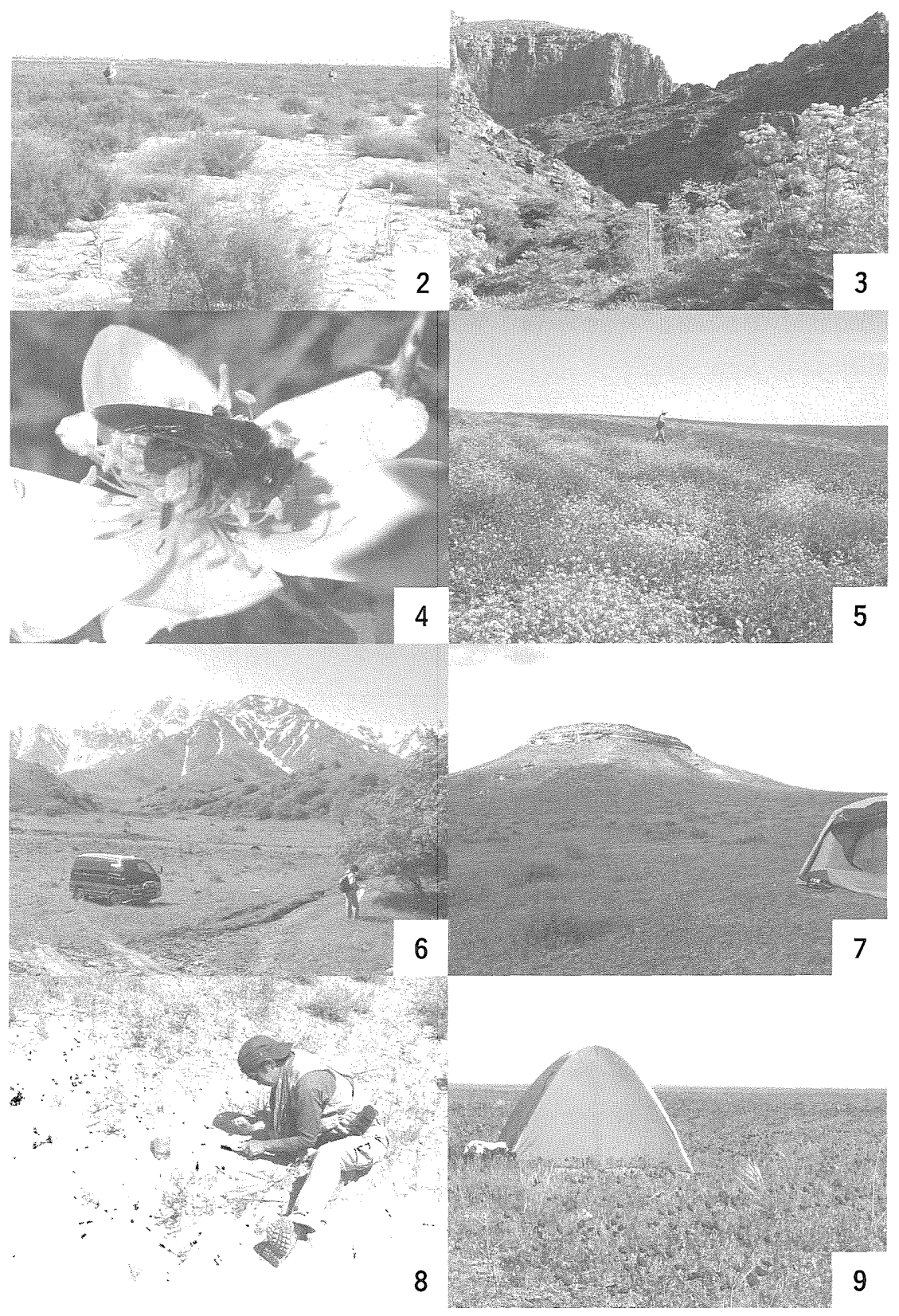

Figs. 2-9. 2: Field survey in Urmuqi, China; 3: Mts. Karatau, Kazakhstan (KZ); 4: Andrena (Melandrena) sp.; 5: Esat of Chimkent, KZ; 6: Akus-Jabagly, KZ; 7: Kyzylkum Desert, KZ; 8: Field study of nesting site; 9: Muyunkum Desert. $\mathrm{KZ}$. 
Andrenidae

(1) Andrena (Euandrena) sp.

Studied area: Jeminay, Xinjiang Uygur Autonomus Region, China

Studied year: August, 2002

Associated plant: Chondrilla brevinotris (Compositae)

We describe this new species with a nesting structure in a separate paper (Esakia, 45: 917).

Halictidae

(2) Halictus sp. 1

Studied area: Daubaba, Kazakhstan

Studied year: June, 2003

(3) Halictus sp. 2

Studied area: Kamsomolskoe, Kazakhstan

Studied year: May, 2004

(4) Halictus sp. 3

Studied area: Kyzylkum Desert, Kazakhstan

Studied year: May, 2004

(5) Halictus sp. 4

Studied area: Syrdaria Riverside, Kazakhstan

Studied year: May, 2004

(6) Halictus sp. 5

Studied area: Jabagly, Kazakhstan

Studied year: June, 2003

(7) Lasioglossum sp. 1

Studied area: Almaty, Kazakhstan

Studied year: May, 2004

Megachilidae

(8) Megachilinae sp. 1

Studied area: Kyzylkum Desert, Kazakhstan

Studied year: May, 2004

Associated plant: Alhagi pseudoalhagi (Leguminosae)

(9) Megachilinae sp. 2

Studied area: Kyzylkum Desert, Kazakhstan

Studied year: May, 2004

Associated plant: Alhagi pseudoalhagi (Leguminosae)

(10) Megachilinae sp. 3

Studied area: Murunkarak, Kazakhstan

Studied year: May, 2004 
Apidae

(11) Anthophora sp. 1

Studied area: Jabagly, Kazakhstan

Studied year: June, 2003

(12) Anthophora sp. 2

Studied area: Almaty, Akus-Javagly, Kazakhstan

Studied year: June, 2003

\section{Ackmowledgements}

I am very grateful to the Zoological Institute of the Kazakhstan Academy of Sciences (Almaty), the Zoological Institute of the Chinese Academy of Sciences (Dr. Dawei Huang, Beijing) and Xinjiang Agricultural University (Urumuqi) for their kind support of our field study. I am indebted to the following entomologists for their participation and assistance in the field survey: Dr. Vitaly Kascheev, Almaty, Dr. Roman Jashenko, Almaty, Dr. DengYuan Wang, Urumuqi, and Dr. ZeQing Niu, Beijing, Dr. R. Miyanaga, Shimane Univ., Dr. S. Ikudome, Kagoshim Women's Junior College, Mr. R. Murao, Kyushu Univ., Mr. K. Mitai, Kyushu Univ., Dr. A. Dawut, Kyushu Univ., Dr. J. Yukawa, Kyushu Univ., Dr. S. Kamitani, Kyushu Univ., Mr. D. Yamaguchi, Kyushu Univ., Miss T. Ganaha, Kyushu Univ. We wish to express our deep gratitude to the Japan Society for the Promotion of Science for financial support for this project.

\section{References}

Dawut, A. \& O. Tadauchi 2001. A systematic study of the subgenus Seladonia of the genus Halictus in Asia (Hymenoptera, Apoidea, Halictidae) II. Esakia, (41) : 106-128.

Dawut, A. \& O. Tadauchi 2002a. A systematic study of the subgenus Seladonia of the genus Halictus in Asia (Hymenoptera, Apoidea, Halictidae) III. Esakia, (42): 121-150.

Dawut, A. \& O. Tadauchi 2002b. A systematic study of the subgenus Seladonia of the genus Halictus in Asia (Hymenoptera, Halictidae). Proc. 5th Intnl. Conf. Hymenopterists, Beijing, China,. p.59.

Dawut, A. \& O. Tadauchi 2003. A systematic study of the subgenus Seladonia of the genus Halictus in Asia (Hymenoptera, Apoidea, Halictidae) IV. Esakia, (43): 97-131.

Dregne, H. E., 1986. Desertification of arid lands. In El-Baz F. \& M. H. A. Hassan (eds.), Physics of Desertification. Dordrecht, the Netherlands.

ECES 2004. Earth Crash Earth Spririt. http://eced.org/archive/ec/ecosystems/ desertification. shtml/

Michener, C. D. 1979 Biogeography of the bees. Ann. Missouri Bot. Garden, 66: 277-347. 
Michener, C. D. 2000. The Bees of the World. Johns Hopkins Univ. Press, Baltimore \& London.

Tadauchi, O. \& H.-1. Xu 2002. A revision of the subgenus Cnemidandrena of the genus Andrena of the eastern Asia (Hymenoptera, Andrenidae). Esakia, (42): 75-119.

Tadauchi, O. \& H.-1. Xu 2003. A revision of the subgenus Taeniandrena of the genus Andrena of the eastern Asia (Hymenoptera, Andrenidae). Esakia, (43): 65-95.

Tadauchi, O. \& H.-1. Xu 2004. The subgenus Cordandrena of the genus Andrena newly recorded from eastern Asia, with a new species (Hymenoptera, Andrenidae). Esakia, (44): 81-90.

Xu, H.-1. \& O. Tadauchi 2001. Supplements to the subgenus Simandrena of the genus Andrena of China (Hymenoptera, Andrenidae). Esakia, (41): 155-160.

Xu, H.-1. \& O. Tadauchi 2002. A revision of the subgenus Chlorandrena of the genus Andrena of the eastern Asia (Hymenoptera, Andrenidae). Esakia, (42): 55-73.

Xu, H.-1., O. Tadauchi \& Y.-r. Wu 2002. A revision of the East Asian subgenus Oreomelissa of the genus Andrena (Hymenoptera, Andrenidae). Proc. 5th Intnl. Conf. Hymenopterists, Beijing, China, p. 58-59. 